\title{
Article/Artigo
}

\section{Evidence of a higher prevalence of HPV infection in HTLV-1-infected women: a cross-sectional study}

\author{
Evidência de maior prevalência de infecção pelo HPV em mulheres infectadas pelo HTLV-1: \\ um estudo de corte transversal
}

\begin{abstract}
Sônia Sampaio Lôpo ${ }^{1}$, Paula Matos Oliveira ${ }^{1}$, Iuri Usêda Santana ${ }^{2}$, Geisa Barbosa Pena ${ }^{2}$, Maria Betânia Torrales ${ }^{3}$, Rita Elizabeth Mascarenhas ${ }^{2,4}$, Bernardo Galvão-Castro ${ }^{1,4}$ and Maria Fernanda Rios Grassi ${ }^{1,4}$
\end{abstract}

\begin{abstract}
Introduction: HTLV-1 infection increases susceptibility to other infections. Few studies have addressed the co-infection between HPV and HTLV-1 and the immune response involved in this interaction. The aim of this study was to determine the prevalence of cervical HPV infection in HTLV-1-infected women and to establish the risk factors involved in this co-infection. Methods: A cross-sectional study was carried out in Salvador, Brazil, between September 2005 and December 2008, involving 50 HTLV-1-infected women from the HTLV Reference Center and 40 uninfected patients from gynecological clinic, both at the Bahiana School of Medicine. HPV infection was assessed using hybrid capture. HTLV-1 proviral load was quantified using real-time polymerase chain reaction (PCR). Results: The mean age of HTLV-1-infected women ( $38 \pm 10$ years) was similar to that of the control group ( $36 \pm 13$ years). The prevalence of HPV infection was $44 \%$ in the HTLV-1-infected group and $22.5 \%$ in uninfected women $(\mathrm{p}=0.03)$. HTLV-1-infected women had lower mean age at onset of sexual life ( $17 \pm 3$ years versus $19 \pm 3$ years; $p=0.03$ ) and greater number of lifetime partners compared with the control group $(4 \pm 3$ versus $2 \pm 1 ; \mathrm{p}<0.01)$. In the group of HTLV-1-infected patients, there was neither difference in HTLV-1 proviral load between HPV-infected women and the uninfected. Conclusions: The prevalence of HPV infection was higher in HTLV-1-infected women. Further studies should be performed to evaluate the progression of this co-infection.
\end{abstract}

Keywords: HTLV-1. HPV. Proviral load. Brazil.

\section{RESUMO}

Introdução: A infecção pelo HTLV-1 aumenta a susceptibilidade para outras infecções. Poucos estudos avaliaram a co-infecção entre HPV/HTLV-1 e a resposta imune envolvida nesta interação. $\mathrm{O}$ objetivo deste trabalho é determinar a prevalência de infecção cervical pelo HPV em mulheres infectadas pelo HTLV-1 e estabelecer os fatores de risco envolvidos nesta co-infecção. Métodos: Um estudo de corte transversal foi conduzido em Salvador, Brasil, entre setembro de 2005 e dezembro de 2008, envolvendo 50 mulheres infectadas pelo HTLV-1, acompanhadas no Centro de Referência de HTLV e 40 mulheres não infectadas, acompanhadas no Serviço de Ginecologia, ambos na Escola Bahiana de Medicina. A infecção pelo HPV foi confirmada pela Captura Híbrida. A carga proviral do HTLV-1 foi quantificada pelo PCR em tempo real. Resultados: A média de idade das mulheres infectadas pelo HTLV-1 (38 \pm 10 anos) foi semelhante ao do grupo controle ( $36 \pm 13$ anos). A prevalência de infecção pelo HPV foi $44 \%$ nas mulheres infectadas pelo HTLV- 1 e de $22,5 \%$ no grupo controle $(p=0,03)$. Mulheres infectadas pelo HTLV-1 informaram menor idade de início de vida sexual ( $17 \pm 3$ anos versus $19 \pm 3$ anos; $p=0,03)$ e maior número de parceiros sexuais, em relação ao grupo controle $(4 \pm 3$ versus $2 \pm 1 ; \mathrm{p}<0,01)$. No grupo de mulheres infectadas pelo HTLV-1, não se observou diferença entre a carga proviral do HTLV-1 entre as mulheres infectadas pelo HPV e as não infectadas. Conclusões: A prevalência de infecção pelo HPV foi maior em mulheres infectadas pelo HTLV-1. Novos estudos devem ser realizados para avaliar a progressão desta co-infecção.

Palavras-chaves: HTLV-1. HPV. Carga proviral. Brasil.

1. Pós-Graduação em Medicina e Saúde Humana, Escola Bahiana de Medicina e Saúde Pública, Salvador, BA. 2. Faculdade de Medicina, Escola Bahiana de Medicina e Saúde Pública, Salvador, BA. 3. Faculdade de Medicina, Universidade Federal da Bahia, Salvador, BA. 4. Laboratório Avançado de Saúde Pública, Centro de Pesquisa Gonçalo Muniz, Fundação Oswaldo Cruz, Salvador, BA.

Address to: Dra. Maria Fernanda Rios-Grassi. Lab. Avançado de Saúde Pública/CPqGM/FIOCRUZ. Rua Waldemar Falcão 121, Candeal, 40296-710 Salvador, BA, Brasil.

Phone: $55713176-2213$

e-mail: grassi@bahia.fiocruz.br

Received in 22/08/2011

Accepted in 20/12/2011

\section{INTRODUCTION}

Human T-cell lymphotropic virus type-1 (HTLV-1) infects approximately 10-20 million people around the world ${ }^{1}$. In Brazil, the highest $(1.7 \%)$ prevalence of infection is in Salvador, a city with about three million people, located in the northeast of Brazil. The infection is more frequent in women, reaching $10 \%$ of prevalence in women above fifty years ${ }^{2}$. HTLV-1 is the etiologic agent of adult T-cell leukemia/lymphoma ${ }^{3}$, HTLV-1associated myelopathy/tropical spastic paraparesis (HAM/TSP $)^{4,5}$, and HTLV-1-associated uveitis ${ }^{6}$. In addition, a higher prevalence of infectious diseases, such as infective dermatitis ${ }^{7,8}$, tuberculosis ${ }^{9,10}$, strongyloidiasis $^{11-13}$, and Norwegian scabies ${ }^{14-16}$, has also been described in HTLV-1-infected individuals.

Human papillomavirus (HPV) is the etiologic agent of one of the most prevalent sexually transmitted diseases in the world and is also directly related to cervical cancer ${ }^{17}$, the third most common cancer in Brazil. The HPV types 16 and 18 are the most frequent types found in cervical squamous cell carcinoma, accounting for more than $70 \%$ of cases $^{18}$. A higher frequency of HPV infection and an increased risk of cervical cancer are found in immunosuppressed women, as can be observed in human immunodeficiency virus (HIV)-infected patients ${ }^{19-21}$. The studies that assessed the association of HPV infection in HTLV-1 patients have not reached a consensus on the epidemiological aspects of this co-infection ${ }^{22-25}$. The aim of this study was to determine the prevalence of HPV infection in HTLV-1-infected women in the City of Salvador, Bahia, Brazil, and to establish the risk factors involved in this co-infection.

\section{METHODS}

A cross-sectional pilot study with a control group was carried out in Salvador, Brazil, between September 2005 and December 2008, involving $50 \mathrm{HTLV}$-1-infected patients and 40 uninfected 
women. All patients were followed at the Bahia School of Medicine and Public Health (EBMSP), Salvador, Brazil. HTLV-1-infected patients were selected from the HTLV Reference Center that has provided comprehensive care to a total of 1,050 patients since 2002 . Of these, $50 \%$ are regularly seen at least twice a year ( $75 \%$ women). Uninfected controls were selected at the Gynecological Outpatient Clinic, located on the same campus. Patients were invited and sequentially included in the study upon their medical visit. Inclusion criteria were positive serology for HTLV-1 (HTLV-1 group), tested negative for HTLV-1 (control group), sexually active, and met criteria for sample collection for Pap smear. Patients with positive serology for HIV, pregnant women, transplant recipients, patients on chemotherapy or steroids, or those with diseases that compromise the immune system were excluded.

The patients answered a questionnaire that assessed demographics, medical, sexual, and gynecological data. After the interview, physical and gynecological examinations were performed. Specimens for Papanicolaou smears were collected from ectocervix and endocervix using an Ayres spatula and cytobrush, respectively. Squamous cell abnormalities seen in the Papanicolaou smears were classified as lowgrade or high-grade squamous intraepithelial lesions, in accordance with the Bethesda System ${ }^{26}$. The cervical samples were collected using a sterile swab and stored in universal collection medium (UCM) solution. The hybridization was performed using the commercial kit supplied by the Digene HPV (São Paulo, Brazil), according to the protocol specified by the manufacturer. The samples were processed in the laboratory of clinical analysis DNA (Salvador, Bahia).

The populations of CD4+ and CD8+ (cluster of differentiation) lymphocytes were analyzed using flow cytometry (FACScan), after labeling cells with monoclonal antibodies and CD3-FITC (fluorescein isothiocyanate) anti-CD4-PE (phycoerythrin) and antiCD8-PerCP (peridinin chlorophyll protein). The HTLV-1 proviral load was measured using the technique of real-time polymerase chain reaction (PCR) after obtaining mononuclear cells from peripheral blood by density gradient and DNA extraction by the commercial kit (QIAGEN, Germany) previously described ${ }^{27}$.
Categorical variables were expressed as absolute values and percentage. Quantitative variables were described as mean and standard deviation or as median and interquartile interval. The Chisquare or the Fischer's exact tests were used to compare categorical variables between groups. The independent Student's t-test was used to compare continuous variables between groups. The association between HPV infection and the presence of HTLV-1 were verified, along with others known risk factors for HPV infection. Unadjusted odds ratio (OR) were calculated to screen for inclusion in an initial multivariate model. Variables that exhibited at least a moderate association with the outcome in the presence of these design variables were considered for inclusion in the final models. The analysis was performed using the SPSS software (Statistical Package for the Social Sciences), version 17.0.

\section{Ethical considerations}

The project was approved by the Ethics Research Center from Gonçalo Muniz Center, Fundação Oswaldo Cruz, Bahia. All patients read and signed an informed consent before being included in the study.

\section{RESULTS}

The mean age of the HTLV-1-infected group was similar to that of the control group. HTLV-1-infected patients had a lower age of first sexual intercourse ( 17 years versus 18.6 years; $p=0.03$ ), a higher number of sexual partners ( 4.1 versus $1.9 ; \mathrm{p}<0.01)$, and a higher number of abortions ( 1 versus $0.5 ; \mathrm{p}=0.02$ ) compared with the control group (Table 1).

The HPV prevalence was higher among HTLV-1-infected women than in the control group ( $44 \%$ versus $22.5 \%$; $\mathrm{p}=0.03$ ) (Table 2). There was no difference in the frequency of HPV type among the groups. One HTLV-1-infected patient showed a highgrade squamous intraepithelial lesion (HSIL), whereas women of the control group had cytological findings classified as normal or inflammatory. There was no difference in the prevalence of HPV

TABLE 1 - Sociodemographic characteristics and sexual antecedents $(\mathbf{n}=90)$.

\begin{tabular}{|c|c|c|c|}
\hline & $\begin{array}{l}\text { HTLV-1-infected patients } \\
\qquad(\mathrm{n}=50)\end{array}$ & $\begin{array}{l}\text { Healthy control } \\
\qquad(\mathrm{n}=\mathbf{4 0})\end{array}$ & $\begin{array}{c}\mathbf{p} \\
\text { value }\end{array}$ \\
\hline Age (years) & $37.8 \pm 10.4$ & $35.6 \pm 13$ & 0.37 \\
\hline long-time relationship & $29(58.0)$ & $19(47.5)$ & \\
\hline single/widow & $21(42.0)$ & $21(52.5)$ & \\
\hline Smoking & $3(6.0)$ & $5(12.5)$ & 0.45 \\
\hline Study (years) & $7.8 \pm 3.6$ & $8.4 \pm 2.2$ & 0.38 \\
\hline$\leq 8$ & 48.0 & 47.5 & \\
\hline$>8$ & 52.0 & 52.5 & \\
\hline Age at first sexual intercourse (years) & $17 \pm 3.4$ & $18.6 \pm 3.3$ & 0.03 \\
\hline Numbers of sexual partners & $4.1 \pm 3.2$ & $1.9 \pm 1.1$ & $<0.01$ \\
\hline Parity & $2.3 \pm 2.6$ & $1.6 \pm 1.4$ & 0.18 \\
\hline
\end{tabular}

HTLV-1: human T-cell lymphotropic virus type-1. Categorical variables were expressed as n (\%). Quantitative variables were described as mean and standard deviation. 
infection among HTLV-infected and uninfected groups when women were stratified into age ranges (15-25, 26$35,36-45,46-55$, and 56-65 years). Four positive cases of HPV infection (18.2\%) were observed in HTLV-infected women with $46-55$ years, whereas none was found in the control group at same age $(\mathrm{p}=0.31)$ (data not shown).

The OR for HPV infection in HTLV-1-infected patients was 2.7 (95\% confidence interval, CI: 0.8-8.2; $\mathrm{p}=0.07)$ after adjusting the variables. The OR of age for HPV infection was 0.9 (95\% CI: 0.8-0.9; $\mathrm{p}=0.03$ ), and the number of sexual partners showed an OR of $1.1 \%$ (95\% CI: 0.9-1.4, p = 0.09) (Table 3). The HTLV-1infected patients with HPV co-infection showed a higher number of sexual partners compared with the HTLV-1infected patients not infected with HPV (5.3 versus 2.6;
TABLE 2 - HPV infection and cytological findings $(n=90)$.

\begin{tabular}{lccc}
\hline & $\begin{array}{c}\text { HTLV-1-infected patients } \\
(\mathbf{n}=\mathbf{5 0})\end{array}$ & $\begin{array}{c}\text { Healthy control } \\
(\mathbf{n}=\mathbf{4 0})\end{array}$ & $\begin{array}{c}\text { p } \\
\text { value }\end{array}$ \\
\hline $\begin{array}{l}\text { HPV infection } \\
\text { HPV group }\end{array}$ & $22(44.0)$ & $9(22.5)$ & 0.03 \\
$\quad$ group A & $2(9.1)$ & $0(0.0)$ & 1.00 \\
$\quad$ group B & $12(54.5)$ & $7(77.8)$ & 0.41 \\
$\quad$ group A+B & $8(36.4)$ & $2(22.2)$ & 0.67 \\
Cytological findings & & & 1.00 \\
$\quad$ normal or inflammatory & $49(98.0)$ & $40(100.0)$ & \\
$\quad$ HSIL & $1(2.0)$ & $0(0.0)$ & \\
\hline
\end{tabular}

Categorical variables were expressed as n (\%). Quantitative variables were described as mean and standard deviation; HTLV-1: human T-cell lymphotropic virus type-1; HSIL: High-grade squamous intraepithelial lesion. $p=0.01)$. There were no observed differences regarding other possible risk factors associated with this co-infection (Table 4).

Regarding immunological features, there was no difference in the HTLV-1 proviral load in patients with HPV infection compared with the group without HPV infection (16,000 copies $/ 10^{6}$ peripheral blood mononuclear cell [PBMC] versus 6,114 copies/10 $10^{6} \mathrm{PBMC}$; $\mathrm{p}=0.42$ ). No difference was observed in the proportion of T-CD4+ lymphocytes in the HTLV-1 and HPV-co-infected patients compared with HTLV-1-infected patients ( $43.8 \pm 10.6 \%$ versus $48.9 \pm 8.6 \%$; $\mathrm{p}=0.1)$ (data not shown).

\section{DISCUSSION}

The present study indicated a higher prevalence of cervical HPV infection in HTLV-1-infected women. The HTLV-1 infection and the number of sexual partners appeared to be associated with increased risk for HPV infection, despite the absence of statistical difference in this study. Only the age of patients had a significant association with HPV infection: younger patients had an increased risk for HPV infection. In spite of the higher frequency of cervical HPV infection in HTLV-1-infected women, there was no occurrence of cervical cancer in these patients.

A few studies have assessed the association between HTLV- 1 and cervical HPV infection. In Japan, a cross-sectional study ${ }^{22}$ observed higher prevalence of HTLV-1 infection in patients with cervical cancer, assigning a threefold higher risk for this malignancy. In Jamaica, a case-control study suggested that HTLV-1 infection was a risk factor for progression of cervical intraepithelial neoplasia ${ }^{23}$. However, another study performed in that same area did not confirm this association ${ }^{24}$. Moreover, a study conducted in Mexico failed to find a relation between HTLV-1 infection and risk for cervical cancer $^{25}$.

As this is a pilot cross-sectional study, involving a small sample size, it was not possible to estimate the prevalence of cervical cancer or premalignant lesions. The absence of cervical cancer in this population could also be explained by the young age of patients, although cervical cancer may occur from the third decade of life; the peak age-specific cervical cancer is around the sixth decade of life $\mathrm{e}^{28}$. Also, it was not possible to identify the HPV types involved in the infections or to determine whether this population has lower tissue viral clearance.

The HTLV-1 infection induces a spontaneous proliferation of lymphocyte subsets. As a result, HTLV-1-infected individuals have an increased population of activated lymphocytes, an
TABLE 3 - Adjusted odds ratio for potential risk factors for HPV infection $(\mathbf{n}=90)$.

\begin{tabular}{lccc}
\hline Variables & Adjusted OR & 95\% CI & p value \\
\hline HTLV-1 infection & 2.7 & $0.8-8.2$ & 0.07 \\
First sexual intercourse & 1.0 & $0.8-1.2$ & 0.63 \\
Numbers of sexual partners & 1.1 & $0.9-1.4$ & 0.09 \\
Age & 0.9 & $0.8-0.9$ & 0.03 \\
Parity & 0.9 & $0.6-1.2$ & 0.57 \\
\hline
\end{tabular}

HPV: human papillomavirus; HTLV-1: human T-cell lymphotropic virus type; OR: odds ratio; CI: confidence interval.

TABLE 4 - Possible risk factors associated with HTLV-1 and HPV co-infection $(\mathbf{n}=\mathbf{5 0})$.

\begin{tabular}{lccc}
\hline & \multicolumn{3}{c}{ HTLV-1-infected patients } \\
\cline { 2 - 4 } & $\begin{array}{c}\text { HPV present } \\
(\mathbf{n}=\mathbf{2 2})\end{array}$ & $\begin{array}{c}\text { HPV absent } \\
(\mathbf{n}=\mathbf{2 8})\end{array}$ & $\begin{array}{c}\text { p } \\
\text { value }\end{array}$ \\
\hline Age (years) & $35.3 \pm 10.2$ & $39.8 \pm 10.3$ & 0.13 \\
Civil status & & & 0.19 \\
$\quad$ long-time relationship & $15(68.2)$ & $14(50.0)$ & \\
$\quad$ single/widow & $7(31.8)$ & $14(50.0)$ & \\
Smoking & $2(9.1)$ & $1(3.6)$ & 0.57 \\
Study (years) & & & 0.14 \\
$\quad \leq 8$ & $8(36.4)$ & $16(57.1)$ & \\
$\quad>8$ & $14(63.6)$ & $12(42.9)$ & \\
Age at first sexual intercourse (years) & $17.0 \pm 2.8$ & $16.9 \pm 3.8$ & 0.87 \\
Numbers of sexual partners & $5.3 \pm 3.9$ & $3.1 \pm 2.2$ & 0.01 \\
Parity & $1.9 \pm 2.2$ & $2.6 \pm 2.9$ & 0.36 \\
Abortions & $1.1 \pm 1.2$ & $0.9 \pm 1.1$ & 0.55 \\
\hline
\end{tabular}

HTLV-1: human T-cell lymphotropic virus type; HPV: human papillomavirus.

Categorical variables were expressed as n (\%). Quantitative variables were described as mean and standard deviation.

increased expression of proinflammatory cytokines ${ }^{29}$, and lower proliferative response to recall antigen ${ }^{30}$, which may induce an immunosuppression. These immunological abnormalities and the highest exposure to risk factors common to HTLV-1 and HPV could explain the high prevalence of HPV infection ${ }^{31}$. Other immunosuppressive diseases are also associated with a high prevalence of HPV infection, such as HIV infection ${ }^{20}$ and systemic lupus erythematosus ${ }^{32}$. However, no difference was found in the proportion of CD4-T lymphocytes and in the HTLV-1 proviral load of HTLV-1-infected patients with HPV, compared with HTLV-1infected women. 
This study indicated that HTLV-1-infected patients are more susceptible to HPV infection than healthy women and the number of sexual partners seems to be involved with the risk for HPV infection. Thus, these patients could benefit from gynecological visits at shorter intervals. Longitudinal studies should be conducted, following a higher number of women infected with HTLV-1 to confirm the HPV prevalence and observe the onset of cervical abnormalities.

\section{ACKNOWLEDGMENTS}

The authors thank Dr. Raymond Césarie for providing HTLV/ Albumina clones and Vivianna Olavarria for the technical assistance in the HTLV proviral load measurements.

\section{CONFLICT OF INTEREST}

The authors declare that there is no conflict of interest.

\section{FINANCIAL SUPPORT}

This study was supported by the Fundacão de Amparo à Pesquisa da Bahia (FAPESB).

\section{REFERENCES}

1. Dourado I, Alcantara LC, Barreto ML, Teixeira MG, Galvão-Castro B. HTLV-I in the general population of Salvador, Brazil: a city with African ethnic and sociodemographic characteristics. J Acquir Immune Defic Syndr 2003; 34:527-531.

2. Proietti FA, Carneiro-Proietti AB, Catalan-Soares BC, Murphy EL. Global epidemiology of HTLV-I infection and associated diseases. Oncogene 2005; 24:6058-6068.

3. Uchiyama T, Yodoi J, Sagawa K, Takatsuki K, Uchino H. Adult T-cell leukemia: clinical and hematologic features of 16 cases. Blood 1977; 50:481-492.

4. Gessain A, Barin F, Vernant JC, Gout O, Maurs L, Calender A, et al. Antibodies to human T-lymphotropic virus type-I in patients with tropical spastic paraparesis. Lancet $1985 ; 2: 407-410$.

5. Osame M, Usuku K, Izumo S, Ijichi N, Amitani H, Igata A, et al. HTLV-I associated myelopathy, a new clinical entity. Lancet 1986; 1:1031-1032.

6. Rathsam-Pinheiro RH, Boa-Sorte N, Castro-Lima-Vargens C, Pinheiro CA, Castro-Lima H, Galvao-Castro B. Ocular lesions in HTLV-1 infected patients from Salvador, State of Bahia: the city with the highest prevalence of this infection in Brazil. Rev Soc Bras Med Trop 2009; 42:633-637.

7. LaGrenade L, Hanchard B, Fletcher V, Cranston B, Blattner W. Infective dermatitis of Jamaican children: a marker for HTLV-I infection. Lancet 1990; 336:1345-1347.

8. Oliveira MF, Brites C, Ferraz N, Magalhaes P, Almeida F, Bittencourt AL. Infective dermatitis associated with the human T cell lymphotropic virus type I in Salvador, Bahia, Brazil. Clin Infect Dis 2005; 40:e90-96.

9. Marinho J, Galvao-Castro B, Rodrigues LC, Barreto ML. Increased risk of tuberculosis with human T-lymphotropic virus-1 infection: a case-control study. J Acquir Immune Defic Syndr 2005; 40:625-628.

10. Moreira Jr ED, Ribeiro TT, Swanson P, Sampaio Filho C, Melo A, Brites C, et al. Seroepidemiology of human T-cell lymphotropic virus type I/II in northeastern Brazil. J Acquir Immune Defic Syndr 1993; 6:959-963.

11. Nakada K, Kohakura M, Komoda H, Hinuma Y. High incidence of HTLV antibody in carriers of Strongyloides stercoralis. Lancet 1984; 1:633.

12. Robinson RD, Lindo JF, Neva FA, Gam AA, Vogel P, Terry SI, et al. Immunoepidemiologic studies of Strongyloides stercoralis and human T lymphotropic virus type I infections in Jamaica. J Infect Dis 1994;169:692-696.

13. Sato Y, Shiroma Y, Kiyuna S, Toma H, Kobayashi J. Reduced efficacy of chemotherapy might accumulate concurrent HTLV-1 infection among strongyloidiasis patients in Okinawa, Japan. Trans R Soc Trop Med Hyg 1994; 88:59.

14. Blas M, Bravo F, Castillo W, Castillo WJ, Ballona R, Navarro P, et al. Norwegian scabies in Peru: the impact of human T cell lymphotropic virus type I infection. Am J Trop Med Hyg 2005; 72:855-857.

15. Brites C, Weyll M, Pedroso C, Badaro R. Severe and Norwegian scabies are strongly associated with retroviral (HIV-1/HTLV-1) infection in Bahia, Brazil. AIDS 2002; 16:1292-1293.

16. Takeshita T, Takeshita H. Crusted (Norwegian) scabies in a patient with smoldering adult T-cell leukemia. J Dermatol 2000; 27:677-679.

17. Almonte M, Albero G, Molano M, Carcamo C, Garcia PJ, Perez G. Risk factors for human papillomavirus exposure and co-factors for cervical cancer in Latin America and the Caribbean. Vaccine 2008; 26 (suppl 11):L16-36.

18. Munoz N, Bosch FX, Sanjose S, Herrero R, Castellsague X, Shah KV, et al. Epidemiologic classification of human papillomavirus types associated with cervical cancer. N Engl J Med 2003; 348:518-527.

19. Nappi L, Carriero C, Bettocchi S, Herrero J, Vimercati A, Putignano G. Cervical squamous intraepithelial lesions of low-grade in HIV-infected women: recurrence, persistence, and progression, in treated and untreated women. Eur J Obstet Gynecol Reprod Biol 2005; 121:226-232.

20. Levi JE, Kleter B, Quint WG, Fink MC, Canto CL, Matsubara R, et al. High prevalence of human papillomavirus (HPV) infections and high frequency of multiple HPV genotypes in human immunodeficiency virus-infected women in Brazil. J Clin Microbiol 2002; 40:3341-3345.

21. Sanjose S, Palefsky J. Cervical and anal HPV infections in HIV positive women and men. Virus Res 2002; 89:201-211.

22. Miyazaki K, Yamaguchi K, Tohya T, Ohba T, Takatsuki K, Okamura H. Human $\mathrm{T}$-cell leukemia virus type $\mathrm{I}$ infection as an oncogenic and prognostic risk factor in cervical and vaginal carcinoma. Obstet Gynecol 1991; 77:107-110.

23. Strickler HD, Rattray C, Escoffery C, Manns A, Schiffman MH, Brown C, et al. Human T-cell lymphotropic virus type I and severe neoplasia of the cervix in Jamaica. Int J Cancer 1995; 61:23-26.

24. Castle PE, Escoffery C, Schachter J, Rattray C, Schiffman M, Moncada J, et al. Chlamydia trachomatis, herpes simplex virus 2, and human T-cell lymphotrophic virus type 1 are not associated with grade of cervical neoplasia in Jamaican colposcopy patients. Sex Transm Dis 2003; 30:575-580.

25. Gongora-Biachi RA, Gonzalez-Martinez P, Castro-Sansores C, Bastarrachea-Ortiz J. Infection with HTLV virus type I-II in patients with cervico-uterine cancer in the Yucatan peninsula, Mexico. Ginecol Obstet Mex 1997; 65:141-144.

26. Solomon D, Davey D, Kurman R, Moriarty A, O'Connor D, Prey M, et al. The 2001 Bethesda System: terminology for reporting results of cervical cytology. JAMA 2002; 287:2114-2119.

27. Dehee A, Cesaire R, Desire N, Lezin A, Bourdonne O, Bera O, et al. Quantitation of HTLV-I proviral load by a TaqMan real-time PCR assay. J Virol Methods 2002; 102:37-51.

28. Goldie SJ, Grima D, Kohli M, Wright TC, Weinstein M, Franco E. A comprehensive natural history model of HPV infection and cervical cancer to estimate the clinical impact of a prophylactic HPV-16/18 vaccine. Int J Cancer 2003 106:896-904.

29. Rios Grassi MF, Mascarenhas RE, Galvao-Castro B. Immunossupressions of HTLV-1-infected individuals: possible immunological mechanisms. Gazeta Médica da Bahia 2009; 79:56-60.

30. Mascarenhas RE, Brodskyn C, Barbosa G, Clarencio J, Andrade-Filho AS Figueiroa F, et al. Peripheral blood mononuclear cells from individuals infected with human T-cell lymphotropic virus type 1 have a reduced capacity to respond to recall antigens. Clin Vaccine Immunol 2006; 13:547-552.

31. Alves DB, Tozetti IA, Gatto FA, Cassandri F, Ferreira AM, Fernandes CES, et al. CD4 and CD8 T lymphocytes and NK cells in the stroma of the uterine cervix of women infected with human papillomavirus. Rev Soc Bras Med Trop 2010; 43:425-429.

32. Santana IU, Gomes AD, Lyrio LD, Rios Grassi MF, Santiago MB. Systemic lupus erythematosus, human papillomavirus infection, cervical pre-malignant and malignant lesions: a systematic review. Clin Rheumatol 2010; 30:665-672. 